\title{
New record of Lecanicillium aphanocladii family: Cordycipitaceae from Egypt
}

\begin{abstract}
New record of the entomopathogenic fungus, Lecanicillium aphanocladii (Zare \& W. Gams) for the first time in Egypt. The detailed description of the cultural and morphological features of $L$. aphanocladii using PDA plates was exhibited in this study. In the meantime, a measurement of its microscopic structures (hypha, phialides and conidia) was carried out using ocular micrometer. The definition of $L$. aphanocladii was confirmed by molecular characterization by $18 \mathrm{~S}$ rRNA gene sequences using [ITS1] and [ITS4] primers.
\end{abstract}

Keywords: lecanicillium aphanocladii, entomopathogen, molecular characterization, ITS, conidia and aphanophialides
Volume 5 Issue 7 - 2017

\author{
Samah Abd El-Kader El-Debaiky \\ Botany Department Faculty of science, Faculty of science, Tanta \\ University, Egypt
}

Correspondence: Samah Abd El-Kader El-Debaiky, Botany
Department, Faculty of Science,Tanta University, Egypt, Tel
00201005256803 , Email Samaheldebaiky@science.tanta.edu.eg

Received: December 13,2017 | Published: December 19, 2017

\section{Introduction}

The fungus Lecanicillium is belonging to the order Hypocreales and is described as anamorphic Cordycipitaceae. This genus is known by its ability to infect other species of fungi such as Agaricus spp., Sphaerotheca spp., ${ }^{1}$ Puccinia spp. ${ }^{2}$ On the other hand, it was recorded as entomopathogenic fungus as it can parasitize some species of insects like Mosquito larva $e^{3-6}$ Bombyx mori, Trialeurodes vaporariorum. In the meantime, it is reported from leaf litter of Abelmoschus esculentus and Acacia karroo. Currently, there are 21 described species of Lecanicillium. ${ }^{7}$ In the past, this genus was described as Verticillium lecanii (Zimmerman) Viegas.

The species $L$. aphanocladii was described for the first time by Zare and Gams, $2001^{8}$ as fungicolous fungus causing cobweb and spotting in the cultivated Agaricus mushroom. There are two synonyms (Exepitypes) of $L$. aphanocladii where it was earlier identified as:

I. Acremonium aranearum (Petch): preserved in MycoBank under the strain number: MB\#144303.

II. Aphanocladium aranearum (Petch) W.Gams: preserved in MycoBank under the strain number: MB\#308804. This species was also known as Aphanocladium album (sensu stricto).

The present study introduces a new record of $L$. aphanocladii in Egypt. It was discovered as a contaminant of some prepared PDA plates which stored in the laboratory at room temperature (about $26^{\circ} \mathrm{C} \pm 2$ ). This contamination was predicted to be due to the passage of some small insects like mites within the PDA plates. Accordingly, the present study aimed to purify the fungus and describing its cultural and morphological features in detail. The identification of the new recorded $L$. aphanocladii was confirmed according to molecular characterization and DNA sequencing.

\section{Materials and methods}

\section{Preparation of potato dextrose agar medium (PDA):}

The used medium in this study was $\mathrm{PDA}^{9}$ which composed of $(\mathrm{g} / \mathrm{L})$, potato tubers, 200, D-Glucose, 20, agar, 20. The potato tubers were peeled, divided to small pieces and boiled in $1 \mathrm{~L}$ distilled water for $1 \mathrm{~h}$.
After boiling, the potatoes were removed by sieve and the filtrate was added to glucose and agar then the mixture volume was completed to one liter with distilled water. Chloramphenicol antibiotic $(0.5 \mathrm{~g} / \mathrm{L})$ was added to prevent bacterial contamination before sterilization in autoclave at $121^{\circ} \mathrm{C}, 1.5 \mathrm{~atm}$. for $15 \mathrm{~min}$.

\section{Identification of the tested fungus}

Morphological characterization: The tested fungus was investigated as a laboratory contaminant on pre-prepared PDA plates. Then it was sub-cultured on new PDA plates in aseptic conditions and incubated for 5 days at $26 \pm{ }^{\circ} \mathrm{C}$. After the incubation period, the macroscopic and microscopic features of the tested fungus were recorded. The macroscopic features included the colony color and appearance, pigmentation at the bottom of the plates while the microscopic features included size and shape of conidia, conidiogenous cells (phialides) and their arrangement on the hyphae.

Molecular characterization: Molecular characterization of the fungal strain was carried out by sequencing of rRNA gene with the help of Solgent Company, Daejeon South Korea. The fungal mycelium was grown on PDA plates at $28^{\circ} \mathrm{C}$ for 7 days. A small portion of the mycelium was scraped and suspended in $100 \mu 1$ autoclaved distilled water in $2 \mathrm{ml}$ sterile vials and boiled at $100^{\circ} \mathrm{C}$ for 15 minutes. DNA was extracted and purified from the non-living fungal mycelia using SolGent purification bead. Prior to the sequencing, the ribosomal rRNA gene (rDNA) was amplified using the polymerase chain reaction (PCR) technique. Two universal fungal primers ITS1 (forward) and ITS4 (reverse) were incorporated in the reaction mixture in PCR technique. ${ }^{10}$ The sequence of each primer is: ITS1 (5, - TCC GTA GGT GAA CCT GCG G - 3'), and ITS4 (5'- TCC TCC GCT TAT TGA TAT GC -3'). The purified PCR products (amplicons) were reconfirmed using a size nucleotide marker (100 base pairs) by electrophoreses on $1 \%$ agarose gel. Then these bands were eluted and sequenced with the incorporation of dideoxynucleotides (dd NTPs) in the reaction mixture. Each sample was sequenced in the sense and antisense directions using ITS1 and ITS4 primers. ${ }^{10}$ Sequences were further analyzed using Basic Local Alignment Search Tool (BLAST) from the National Center of Biotechnology Information (NCBI) website. Phylogenetic analysis of sequences was done with the help of MegAlign (DNA Star) software version 5.05. 


\section{Results and discussion}

\section{Identification of the tested fungus}

The tested fungus was identified as $L$. aphanocladii based on its morphological characters which then confirmed and supported by the molecular characterization. The culture of the new recorded L. aphanocladii was deposited at the mycological center, Assuite University, Assuite, Egypt with strain number (AUMC11913).

\section{Morphological characterization of L. aphanocladii}

Macroscopic features: Colonies of $L$. aphanocladii were fast growing reached $3-5 \mathrm{~cm}$ in 4 days on PDA medium. They were characterized by their white color and high on the surface of the medium (Figure 1A) The bottom of the plates appeared with reddish reverse (Figure 1B).
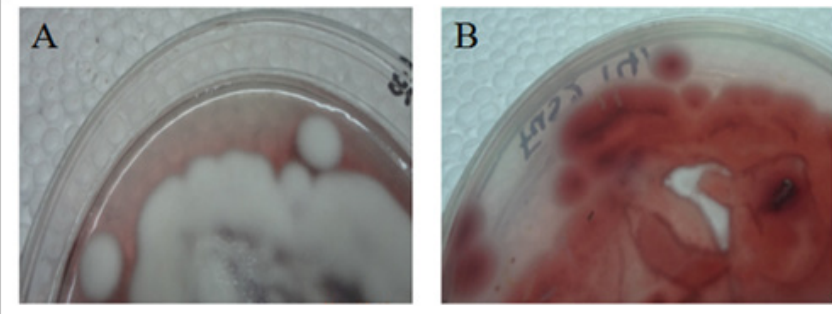

Figure I Culture appearance of L. apanocladii on PDA plates (A) and its reverse $(B)$.

Microscopic features: The phialides of $L$. aphanocladii were characteristic as aphanophialides which protrude solitary, paired or in cluster on the prostrate hyphae (Figure 2A, 2C \& 2D). The aphanophialides were cylindrical shaped $\left(11.5^{\times} 2.6 \mu\right)$, oval shaped with small neck $\left(3.6-4.7^{\times} 1.5-1.9 \mu\right)$ or flask shaped with long tapered neck $\left(7^{\times} 1.7 \mu\right)$. Solitary conidium was observed attached to the apex of each phialide. Conidia were characteristic by different shapes; subglobose $\left(3.5^{\times} 2.9 \mu\right)$, oval $\left(4.9^{\times} 3.2 \mu\right)$ or ellipsoidal shaped $\left(5.7^{\times} 2.4 \mu\right)$. They were generated either as phialo-conidia (Figure 2A, 2C \& $2 \mathrm{D}$ ) or directly on the hyphae (Figure $2 \mathrm{~B}$ ). These morphological characteristics of L. aphanocladii agreed the description recorded by Zare. $^{8}$

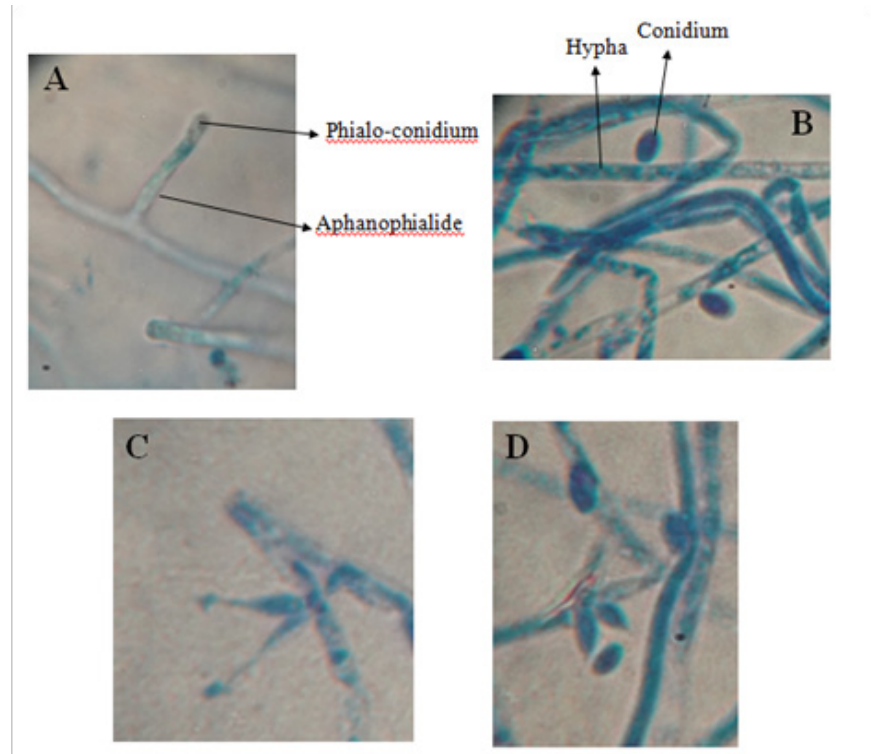

Figure 2 Microscopic structures of L. apanocladii. Cylindrical shaped aphanophialide carrying phialo-conidium (A), conidia generated directly on the hypha (B), paired aphanophialides (C) and aphanophialides in cluster (D).

\section{Molecular characterization}

The resulted data from rDNA sequencing process of the tested isolate were deposited in the GenBank with accession numbers listed in Table 1. A BLAST search for the $18 \mathrm{~S}$ sequences of the tested isolate, L. aphanocladii (AUMC11913) indicated that it was 100\% similar to three Chinese isolates of L. aphanocladii (JX241644, JF911775 and KX530079) Table 1. The present isolate along with another recorded seven isolates of $L$. aphanocladii were subjected to a phylogenetic analysis using available ITS rDNA sequence data downloaded from GenBank (Table 1)

Table I Molecular identification of the tested fungus (AUMCII9I3) and percentage similarities with related strains accessed from the GenBank

\begin{tabular}{|c|c|c|c|c|c|}
\hline \multirow[t]{2}{*}{ Strain No. } & \multirow[t]{2}{*}{ Identification } & \multicolumn{4}{|c|}{ Closely related strains } \\
\hline & & Strain no. & Source/Country & Accession no. & Similarity (\%) \\
\hline & & GL0836 & Apple / China & $J \times 24 I 644$ & 100 \\
\hline & & HQ69 & Lake / China & JF9II 775 & 100 \\
\hline \multirow[t]{4}{*}{ AUMC 11913} & Lecanicillium aphanocladii & ------- & Red spot of Tremella / China & KX530079 & 100 \\
\hline & & FSI3 & Leaves of Hupezia / China & KP689216 & 99.09 \\
\hline & & FJTL & Tobacco / China & $\mathrm{KJ} 162356$ & 99.88 \\
\hline & & DPIILA & Leaves mining insects / Lithuania & KC574075 & 99.66 \\
\hline \multicolumn{2}{|c|}{ Outgroup strain= Lecanicillium lecanii } & PAI96 & Entomopathogenic & AFI72335 & ---------- \\
\hline
\end{tabular}

The Phylogenetic tree of $18 \mathrm{~S}$ sequences showed that my isolate clustered with L. aphanocladii isolates reported elsewhere (Figure 3). The isolate L. lecanii AF172335 was included as an out-group strain where it does not cluster with the L. aphanocladii isolate reported in this study. The resulted data of molecular and phylogenetic analyses supported the morphological identification of my isolate as $L$. aphanocladii.
Later and for a long time, the fungus $L$. aphanocladii has been confused with the species, Aphanocladium album (Preuss) W. Gams, but the genetics studies on the compatibility among fungal species improved that the two taxa are phylogenetically quite unrelated. ${ }^{11,12}$ On the other time, a recent study revealed that there is a close relationship between L. aphanocladii and L. psalliotae based on the ITS phylogeny analysis. ${ }^{13}$ 


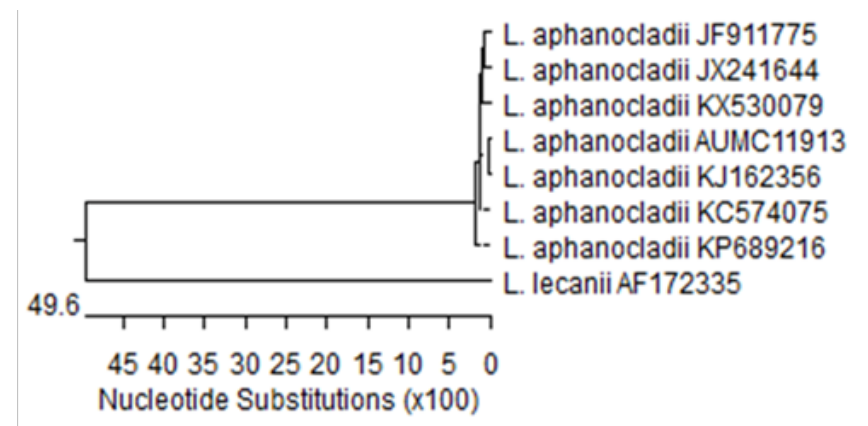

Figure 3 Phylogenetic tree of $18 \mathrm{~S}$ sequences of the fungal strain isolated in the present study (L. aphanocladii AUMC I I9I3; arrowed) aligned with closely related sequences of strains accessed from the GenBank. $L$. = Lecanicillium, $L$. lecanii AFI72335 is included as an out-group strain.

\section{Conclusion}

In the present study, L. aphanocladii was recorded for the first time in Egypt. The fungus was observed as a laboratory contaminant in stored PDA plates. It was identified morphologically according to its culture appearance and microscopic structures. This identification was confirmed and supported by the molecular characterization of the fungus using the $18 \mathrm{~S}$ sequences where it shows $100 \%$ similarities with other 6 isolates of the fungus recorded in the GenBank.

\section{Acknowledgements}

I would like to express my sincere thanks to Prof. Dr. Ahmed Moharram, mycological center, Assuit University, Egypt for his valuable assistance.

\section{Conflict of interest}

The author declares no conflict of interest.

\section{References}

1. Verhaar MA, Kerssies A, Hijwegen T. Effect of relative humidity on mycoparasitism of rose powdery mildew with and without treatments with mycoparasites/Der Einfluss von relativer Luftfeuchtigkeit auf die Bekämpfung von Echtem Mehltau an Rosen mit und ohne Behandlungen mit Mykoparasiten. Zeitschrift für Pflanzenkrankheiten und Pflanzenschutz/Journal of Plant Diseases and Protection. 1999;106:158-165.
2. Völker K, Boyle C. Bean rust as a model system to evaluate efficiency of teliospore inducing mechanisms in dicotyledonous rusts, especially as a possible mycoherbicide of Puccinia punctiformis. Weed Research. $1994 ; 34: 275-281$.

3. López Lastra CC, García JJ, Reboredo GR. Efecto de la temperatura y la salinidad sobre la viabilidad y producción de conidios en los hongos entomopatogenos Tolypocladium cylindrosporum y Aphanocladium album:deuteromycotina:hyphomycetes. Bol micol. 1991;6:43-47.

4. Lastra CL, Garcia J, Micieli M. Microecology of entomopathogenic fungi from aquatic environments [Documentos Embrapa Soja]. Londrina, Brazil: Embrapa Soja; 2002. 184:83-85.

5. Patil C, Krishna M, Shardamma P. New record of fungal pathogen, Aphanocladium album (Preuss) Gams isolated from mulberry silkworm Bombysx mori L. from India. Entomon. 1994;19:175-175.

6. Encheva L. Influence of some factors on the development of the superparasite fungus Aphanocladium album Gams. as a bioagent against glasshouse white fly larvae. Gradinarska i lozarska nauka. Horticultural and viticultural science. 1979.

7. Kirk P, Cannon P, Minter D, et al. Dictionary of the Fungi. 10th ed. Wallingford, UK; 2008.

8. Zare R, Gams W. A revision of Verticillium section Prostrata. IV. The genera Lecanicillium and Simplicillium gen. nov. Nova Hedwigia. 2001;73:1-50.

9. Moubasher A. Soil fungi in Qatar and other Arab countries. Qatar: The Centre for Scientific and Applied Research, University of Qatar; 1993.

10. White TJ, Bruns T, Lee $\mathrm{S}$, et al. Amplification and direct sequencing of fungal ribosomal RNA genes for phylogenetics. PCR protocols: a guide to methods and applications. 1990;18:315-322.

11. Gams W, O'Donnell K, Schroers HJ, et al. Generic classification of some more hyphomycetes with solitary conidia borne on phialides. Canadian Journal of Botany. 1998;76:1570-1583.

12. Sung GH, Spatafora JW, Zare R, et al. A revision of Verticillium sect. Prostrata. II. Phylogenetic analyses of SSU and LSU nuclear rDNA sequences from anamorphs and teleomorphs of the Clavicipitaceae. Nova Hedwigia. 2001;72:311-328.

13. Kumar CS, Jacob T, Devasahayam S, et al. Isolation and characterization of a Lecanicillium psalliotae isolate infecting cardamom thrips (Sciothrips cardamomi) in India. Bio Control. 2015;60(3):363-373. 